\title{
Effects of Interest on Demand Deposits: Implications of Compensating Balances
}

\author{
R. ALTON GILBERT
}

AEGISLATION is being considered which would allow depository financial institutions throughout the nation to offer to households interest-paying checking accounts, more popularly known as NOW (Negotiable Order of Withdrawal) accounts. Bankers, in general, are concened about the effects on earnings of such a regulatory change. Several studies of NOW accounts, however, suggest that this concem may be unjustified, as only small earnings effects have been detected in areas where NOW accounts are currently permitted. ${ }^{1}$

One of the reasons for the expectation of small effects on bank earnings due to nationwide NOW accounts can be traced to the ways by which banks are currently circumventing the prohibition of interest on demand deposits by offering services to depositors at no charge or at low rates. The primary service offered to households is the processing of checks written and deposited by these customers. In effect, this amounts to implicit interest payments. Thus, permission for nationwide NOW accounts would have the most pronounced effect on the form in which banks pay demand deposit interest, with direet interest payments replacing indirect, or implicit, interest payments.

Those studies also suggest that future earnings effects of NOW accomnts are likefy to be reduced as more banks require mininum balances and/or charge for previously free services. See Ralph C. Kimball, "Recent Developments in The NOW Account Experiment in New Ergland," New England Economic Reniew, Federal Reserve Bank of Boston (November/December 1976), pp. 3-19; Kimball, "Impacts of Now Accomts and Thrift Institution Competition on Selected Small Commercial Banks in Massachusets and New Hampshire, 1974-75," New England Economic Review (January/February 1977), pp. 22-38; and Jom D. Patus, "Eiffects of "NOW" Acconnts on Costs and Earnings of Commercial Banks in 1974-75," Staff leonomic Studies, Board of Governors of the Federal Reserve System, 1976.

"David C. Cates and Samuel B. Chase, Ir., The Poyment of Interest on Checking Accounts, a report io the South Carolina Bankers Association, February 1976; Charles F. Haywood, "Possible Effects of Payment of Interest on Demand Deposits," in Studies on the Poument of Tnterest on Checking Accounts (Washington, D.C.: American Bankers Association, 1976), pp. 1-11; Charles Hofman and Tarlene Meman,
This article is concerned with the same sort of analysis of interest-bearing demand deposits, only as it applies to business accounts." Although business accounts have not been given serious consideration in the discussion of permitting interest-bearing demand deposits, it seems likely that a favorable experience with interest-bearing household accounts could lead to the lifting of the interest-paying prohibition on all demand deposits. ${ }^{4}$ The analysis involves an examination of compensating balances, or the demand deposit balances banks require from firms in compensation for preferential loan terms or low-priced services.

\section{THE ROLE OF COMPRNSATMG BALNCE WEOUIIENENTS WN THE COMPETITON AMONG BNDS TOR

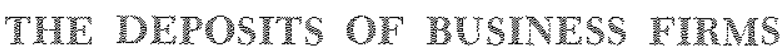

Bank policies of requiring compensating balances from business firms are considered since, as revealed

"Now Acconts in New England" Studies on the payment of Interest on Checking Accotnts, pp. 23-38; William A. Longbrake, "Commercial Bank Capacity to Pay Interest on Denand Deposits, Part II; Eamings and Cost Analysis," Journal of Bank Reseatch (Summer 1976), pp. 134-49. Carl C. Nielsen, Bottom Line Studty for Kansas Banks, prepared for the Kansas Bankers Association, May 1977; Staff Study, Board of Govemors of the Federal Reserve System, The Impact of the Payment of Interest on Demand Deposits, Jatuary 31,1977

"A recent regulatory clange has made the prohibition of interest payments on the demand deposits of business firms less effective. Banks are now permitted to offer sayings accomts to business firms tip to $\$ 150,000$ per firm. The firms that take advantage of another regulatory change which allows banks to transfer funds between their checking and savings acconnts based upon telephone instruction are able to keep part of their working balances in interest eaming accounts. However, these changes in regulations significantly aftect the cash inanagement of only relatively snall fims.

'Two recent studies consider very briefly the wffects on banks of interest on demand deposits of business finms. Both studies conchude that sach interest payments would have minimal effects on bank earnings. See Cates and Chase, The Payment of Interest on Cheching Accounts, p. vili, and Staff Study, Beard of Governors, The Impact of the Poument of Interest on Demand Deposits, pp. 4445 . 
in several studies cited below, most bank lending arrangements with business firms involve compensating balance requirements. Therefore, if banks are currently paying implicit interest on demand deposit balances of business firms, such bank policies would tend to be reflected in the nature of compensating balance requirements.

Differing views are held as to why banks require compensating balances. One view is that banks require compensating balances simply to increase the return on loans. Another view is that compensating balances serve as partial collateral for loans.

Of these two explanations, the argument that banks attempt to increase their retums on loans by requiring borrowers to hold demand balances is discussed more frequently in the banking literature.$^{5}$ According to this view, a bank requires a borrower to leave some proportion of its loan with the bank as an idle demand deposit balance. Under this arrangement the effective yield on lending to the customer is higher than the stated rate on its loan, since the customer has use of only a portion of the total loan on which it is paying interest. While only a few economists explicitly state this view of compensating balances, many apparently support it when they clain that the true costs of borrowing at commercial banks must be adjusted upward from stated loan rates to reflect the additional cost of holding idle compensating balances.

The accuracy of this explanation of compensating balances can be tested, since it has several implications for behavior. For example, the stated interest rates on loans to bonowers that hold compensating balances would tend to be lower than the interest rates on loans to borrowers that do not hold compensating balances. Also, banks would set compensating balance requirements in terms of minimum balances, since compensating balances would represent simply the borrowed funds which customers are not allowed to use, and not their working balances. Consequently, demand deposit balances of borrowers holding compensating balances would tend to be at least some minimum fraction of their outstanding loans at all points in time. These inferences would also follow from the explanation that compensating balances serve as a form of partial collateral for loans.

sFor a discussion of this explanation of compensating balances, see the following articles by Paul S. Nadler: "Compensating Balmoes and the Prine at Twiliht," Hartard Business Revete (Jamary-Febmary 1972), pp. 112 20; and "A Doublul Device Fren Before Lance," New York Times, September 25,1977 , p. F16.
A third view of compensating balances is that banks require them as part of agreements that involve payment of implicit interest on the demand deposits that business firms use as their working balances. Business firms hold working balances to finance their transactions, but banks are not allowed to compete for those deposits with offers of direct interest payments. Operating under this constraint on bank competition, firms shop to find banks which, in return for deposit of their working balances, will offer loans at lowest interest rates and lowest fees for services. To insure that they are compensated for preferential loan terms and low fees on services, banks require that firms keep certnin average demand deposit balances. Thus, firms can use their deposits that serve as compensating balances for their working balances, drawing them down when making expenditures and letting them accmulate when receiving payments.

If this third interpretation of compensating balance requirements is correct, banks would tend to offer better loan terms and lower fees on services to their depositors than to nondepositors, but also, banks would set compensating balance requirements in terms of average balances, rather than minimum. Therefore, at any point in time, demand deposit balances of customers holding compensating balances would not necessarily be some minimum proportion of their loans outstanding.

Several reasons can be given for accepting the view that compensating balance requirements reflect pay. ment of implicit interest on the working balances of business firms, and thus, for rejecting the view that banks require compensating balances just to raise the effective interest rates on loans. If banks require firms to hold idle compensating balances to increase their effective yields on loans, both banks and their customers could benefit from eliminating such compensating balance reguirements, except when usury ceilings are effective. The same reasoning can be used to indicate why requiring minimm compensating balances would be an unprofitable way of charging for use of bank services or of requiring borrowers to provide collatem for loans. However, as indicated in the Appendix, both banks and their borrowers can benefit from average compensating balance requirements satisfied by the customers' working balanees.

Also, evidence on banking practices presented in the following section indicates that most banks allow their business customers to meet compensating balance requirements with averige balmces, instead of setting minimum balance recuirements, This result 
supports the view that banks are paying implicit interest on the working balances of business firms.

Finally, compensating balances are most frequently imposed upon relatively latge fims by large banks, as noted in several surveys of banking practices. The market for loans to the relatively large fims is generally believed to be the most competitive market for bank lonns. Therefore, these observations are consistent only if compensating balance requirements re flect competition by banks for demand deposits.

\section{A SUREY OP EVIUENCE}

Two conditions are necessary if compensating balance requirements are to be interpreted as part of arrangements by which banks pay implicit interest on the demand deposits that their business borrowers use as working balances:

(a) Depositors receive better loan terms than nondepositors with similar risk characteristics or receive services at lower fees than nondepositors.

(b) Banks allow firms to meet compensating balance requirements with their average balances.

\section{Loan Terms and Tees on Services for Depositors}

Several studies present evidence that business firms do receive preferential loan terms when they borrow where they hold demand deposit accounts. ${ }^{6}$ A recent stady of reports by corporations to the Securities and Exchange Commission provides additional evidence of preferential loan terms for depositors. In reports from a sample of corporations, about half of the firms borrowing at banks under compensating balance requirements reported that banks offered options of borrowing at higher interest rates without compensating balance requirements, even though such information was not requested in the reports.

-Donald P. Jacobs, Business Loan Costs and Bank Market Structure: An Empirical Estimate of Their Relations, National Bureau of Economic Research, Occasional Paper 115 (New York: Columbia University Press, 1971); Neil Murphy, A Study of Wholesale Banking Behaviot (Federal Reserve Bank of Boston, 1969), pp. 60-67; James Cooper, "The Demand for Bank Outmuts and the Bank-Customer Relationship," Ph. D. dissertation, University of Illinoss, 1967 , pp. 105-22; and Donald Hester, "An Empirical Examination of a Commercial Bank Loan Offer Function," Studies in Portfolio Behavior (New York: John Wiley and Sons, Ine., $1967)$, p. 165 .

TThe stady is based upon financial statements of 100 corpora tions for 1975. About 60 percent of these firms reported borrowing under compensating balance requirements. Of the other fims, about half had no shortterm domestic bank borrowings. See Pichard Kolodny and Peter Seeley, "The
Evidence that firms receive implicit interest on their demand deposit balances in the form of services is available from studies of account analysis by banks. A bank conducting account analysis keeps records on services used by a business customer, calculates the average level of demand deposits in the customer's account that are necessary to compensate the bank for services used, and analyzes the customer's demand deposit balance to determine whether it is generally large enough to compensate the bank for the services used without charging explicit fees. A study of account analysis at 130 major U.S. banks conducted by the Kansas City Federal Reserve Bank in July 1976 lists balance requirements for 31 separate corporate services. ${ }^{8}$

Indirect evidence that banks have been paying implicit interest on demand deposits is found in a study by Klein." He estimated an implicit rate of return that banks would have been paying on demand deposits under the assumption that banks are competitive. Equations which estimate the aggregate demand for money were improved significantly by including this estimated rate of retum on demand deposits as an explanatory variable. Klein's study indicates that, in adjusting cash holdings to changes in interest rates, the public behaves as though banks are paying interm est on demand deposits. His evidence does not apply specifically to the demand for money by business firms, but since a large proportion of money holdings are by business firms, conclusions concerning determinants of the total demand for money would tend to hold for the money holdings of business firms. ${ }^{10}$

\section{Compensatng Balances as Wonkmg Balances}

Surveys of Banking Practices - Several studies of how barks calculate and enforce compensating balance requirements were conducted in the 1950 s and $1960 \mathrm{~s}$, based on interviews with bankers or questionnaires fllled out by bankers. Those studies indicated that compensating balance requirements were com-

\footnotetext{
Integration of Compensating Balance Theory and Monetary Theory," State University of New York at Binghamton, wimeographed, May 1976.

sFor a discussion of methodology in the account analysis study, see Robert $\mathrm{E}$. Knight, "Account Analysis in Correspondent Banking," Monthly Review, Federal Reserve Bank of Kansas City (March 1976), pp. 11-20.

Benjamin Klein, "Competitive Interest Payments on Bank Deposits and the Long-Rum Demand for Money," American Economic Review (December 1974), pp. 931-49.

10 In 1976 , business firms were estimated to hold about 60 percent of the demand deposits of individuals, partnerships, and corporations.
} 
mon in bank lending agreements with business firms, especially among large banks lending to large firms. ${ }^{11}$ The bases on which compensating balance requirements are determined vary among banks, as proportions of actual borrowings, credit lines, or both. Whatever the amount of compensating balances, the surveys revealed that banks generally allowed firms to meet these requirements with average annual balances. The primary exception was arrangements with finance companies, which were often required to hold minimum compensating balances. ${ }^{12}$

A survey of compensating balance practices conducted by Burns in 1971 yields results which are very similar to those of the older studies cited above. ${ }^{13}$ His survey included 109 banks in the Eleventh Federal Reserve District. All banks in the survey with total deposits over $\$ 500$ million required compensating balances of borrowers, whereas less than half of the banks with total deposits under $\$ 50$ million did so. All of the banks with total deposits over $\$ 100$ million allowed firms to meet compensating balance require-

${ }^{11}$ Nevins D. Baxter and Harold T. Shapiro, "Compensating" Balance Requirements: "The Results of a Survey," Joutnal of Finance (September 1964), pp. 483-96; Caroline $H$. Cagle, "Credit Lines and Minimum Balance Requirements," Federal Reserve Bulletin (Jme 1956), pp. 573-79, F. P. Gallot, "Why Compensating Balances? Part II," Bulletin of the Robert Morris Associates (August 1958), pp. 309-19; William E. Gibson, "Compensating Balance Requitements," National Banking Review (March 1965), pp. 387-95; Douglas A. Hayes, Bank Lending Policies: Issues and Practices (Ann Arbor, Michigan: Bureau of Business Research, University of Michigan, 1964); Donald Hodgman, Commercial Bank Loan and Investment Policy (Champaign, Illinois: Burean of Economic and Business Research, University of llinois, 1963), pp. 24-26; Thomas Mayer and Ira O. Scott, Jr., "Compensating Balances: A Suggested Interpretation," National Banking Review (December 1963), pp. $157-66$.

12By experience, banks can anticipate that, given the demand by firms in most industries for short-term credit and transactions balances, their average demand deposit balances will be large enough, in relation to their average borrowings, to make the conbined business with those fims profitable, even when lerding to them at preferential rates. The demand for short-term credit relative to transactions demand for money is higher for finance companies than for firms in many other industries, If banks allowed fims in financial industries to use their demand deposits as working balances with no minimum deposits required they could not anticipate profitable business with such firms if their loans were at the preferential rates given other depositors. Therefore, financial frms that prefer the prestige of being prime borrowers hold demand deposit balances at the lending banks and accept mintmum deposit balance restrictions. See Jack $M$. Guttentag and Richard G. Davis, "Compensating Balm ances," Monthly Review, Federal Reserve Bank of New York (Decenber 1961), pp. 205-10; Davis and Guttentag, "Are Compensating Balance Requirements Irrational?" Joumal of Finance (March 1962), pp. 121-26.

13Joseph E. Burns, "Compensating Balance Requirements Integral to Bank Lending," Business Peview, Federal Reserve Bank of Dallas (February 1972), pp. 1-8. ments by using average deposit balances, whereas about 20 percent of the smaller banks that use compensating balance requirements required minimum balances.

Studies of whe Domand for Money bu whrs - Two recent studies examine the nature of compensating balance requirements by estimating the influence of the level of bank loans by individual firms on their demand for money balances. ${ }^{14}$ Both studies use data from quarterly reports made by firms to the Securities and Exchange Commission. The money balances reported by firms (as of four days each year at quarterly intervals) are estimated as a function of sales or production, short-term interest rates (as measures of the opportunity cost of holding money), holdings of liquid assets, and the level of bank loans outstanding. The quarterly observations are for individual firms.

Bank debt is included as an independent variable to test the influence of compensating balance requirements on money holdings of firms. If banks impose minimum compensating balance requirements on firms, there would tend to be a positive relation among firms between their loans from banks and their demand deposits at any point in time. However, if compensating balance requirements were not enforced, or if they were enforced as average balance requirements, there would be no basis for expecting a positive relation between the deposit balances and bank loans outstanding. Instead, demand deposit balances would fluctuate from day to day, and bank loans outstanding would also be variable for many of the firms in the study.

The influence of bank loans on the money holdings of firms was found to be either negative or insignificant, while other variables were found to have the expected influences. These results are inconsistent with the view that banks impose minimum compensating balance requirements on fims.

Additonal Evidence on Comperating Balancer-.A survey of business loans at banks in the St. Louis area was conducted by the Federal Reserve Bank of St. Louis in the spring of $1968 . .^{5}$ That survey includes information on total loans outstanding by individual

1.Tim Camplell and Leland Brondsel, "the Impact of Compensating Balance Requirements on the Cash Balances of Manufacturing Corponations: An Empirical Study," Joumal of Finance (March 1977), pp. 31-40; C. Robert Coates, The Demand for Money by Firms (New York: Marcel Dekker, Inc., 1976), pp. 148-54.

tspetaled results from this study are available from the anthor npon request. 
borrowers, their average demand deposit balance during the month of the survey if they had a demand deposit account where they borrowed, activity in those demand deposit accounts, and the industrial classification of borrowers.

Data from this survey can be used to analyze the nature of compensating balance requirements. One approach is to examine the distribution of the ratios of demand deposit balances to loans outstanding among individual borrowers that have demand deposit accounts where they borrow. Data from the survey provide approximations to the demand deposit balances and loans outstanding of borrowers as of a point in time, since the measure of demand deposit balances is average balances over a month, and loans outstanding are reported as of the end of that month.

If banks impose minimum compensating balance requirements, the observed deposit-to-loan ratios of individual customers at any point in time would be at or above the required compensating balance ratios. Firms observed to have ratios of demand deposits to loans outstanding higher than the required compensating balance ratios would be those that had just received large cash inflows at the time of the survey and those that generally hold higher deposit balances in relation to their loans outstanding than banks require. However, if compensating balance requirements are enforced in terms of average balances, the deposit-to-loan ratios of individual borrowers at a point in time would be distributed widely above and below the average compensating balance ratios that are required.

In this study deposit-to-loan ratios were found to be distributed widely above and below the ratios mentioned in the banking literature as required compensating balance ratios. For instance, at most banks in the survey, over half of the customers with demand deposit accounts where they borrowed held demand deposit balances which were less than ten percent of their loans outstanding. One exception to this involves firms in financial industries. Their deposit-to-loan ratios tended to be more concentrated in the range from 10 percent to 30 percent than for other borrow ers, supporting the view expressed above that minimum compensating balance requirements are enforced more frequently on financial firms than on firms in other industries.

Another approach to investigating the nature of compensating balances involves analyzing the "idle" demand deposit balances held by business fims. If compensating balances just represent part of bank loans that borrowers are required to hold as demand deposit balances in some fixed proportion to the amount of their loans, borrowers would not have incentives to hold their working deposit accounts where they borrow. Under such conditions demand deposit accounts of business firms that borrow at banks where they do not keep their working balances would be "idle," that is, have no debits or credits. On the other hand, the demand deposit accounts of business borrowers would tend to be active accounts, that is, have frequent debits and credits, if compensating balances are generally the working balances of firms.

Survey results indicate that for banks of various sizes, idle demand deposit balances of their business borrowers are one percent or less of their total demand deposit liabilities. Also, of the idle demand deposit balances held by firms, a substantial proportion was held by firms in financial industries. Thus, almost all of the demand deposit balances held by business firms at banks where they borrow appear to be working balances.

\section{MPLICATIONS OF INTEREST PAMMENTS ON DEMAND DEPOSTTS FOR BANKS AND THEIR BUSINESS CUSTOMENS}

\section{Would Banks Pay Expled Mnerest on Demand Deposing}

The evidence presented above indicates that banks are paying implicit interest on the working balances of business firms. Given that banks and their business customers have found means of circumventing the prohibition of interest on demand deposits, would banks be induced to pay explicit interest on demand deposits if given permission to do so, or would banks and their customers be satisfied with current arrangements for compensating depositors? Implications of interest on demand deposits for banks and their business customers developed in the following sections are based upon the assumption that banks would pay explicit interest on demand depusits of business firms if given permission to do so.

One set of circumstances under which banks would tend to offer explicit interest would be is, under the prohibition on interest payments, banks had been offering their depositors different implicit interest rates. Banks could do so if they could take advantage of varying degrees of information that customers have 
about banking services that are available in return for their deposit accounts. The prohibition of interest payments is conducive to such discrimination. Banks may be able to offer business customers different combinations of credit terms and services without variation in implicit returns becoming common knowledge among bank customers, because of the individualized nature of such packages of credit terms and services.

However, if banks began offering explicit interest on demand deposits and pricing services separately, customers could more easily make comparisons among banks, and therefore, opportunities for discrimination among customers would be reduced. Banks especially interested in expanding the scope of their operations might begin offering explicit interest on deposits to attract customers that had been receiving relatively small implicit retums on their deposit balances at other banks. Those banks attempting to attract more deposits would be able to communicate information to potential customers concerning explicit interest to be paid on demand deposits more easily than information on the availability of various combinations of loan terms and bank services. Under such conditions there would be competitive pressures on other banks to offer explicit interest on demand deposits.

The case for assuming that banks would pay explicit interest on demand deposits does not depend, however, upon bank discrimination among customers. Even if banks are currently paying competitive implicit rates of interest on the demand deposit balances of all firms, there would also be reasons to expect that banks would begin paying explicit interest if given permission to do so.

If banks set no floor on loan rates to depositors, firms could receive all of their implicit interest on demand deposits in the form of bank loans at relatively low interest rates. Firms with small loan demand relative to their average demand deposit balances would be allowed to borrow at relatively low interest rates in order to provide the same implicit return as that to depositors with relatively larger loan demands.

However, banks generally set the prime rate as the minimum loan rate for all borrowers, including depositors, and surveys indicate that required compensating balance ratios generally vary between 10 percent and 20 percent. Therefore, the beneft a firm receives from its bank in terms of preferential loan terms is limited by its demand for bank loans at the prime rate. Customers which have low loan demands relative to their average demand deposit balances would receive any additional implicit interest in the form of services at no cost or at fees lower than costs to banks of providing the services. Given this pricing structure, the marginal units of bank services would be of little value to many firms, and thus they would not receive the full value of their implicit interest. Such firms would benefit from receiving their interest on deposits directly as cash payments and purchasing bank serv. ices at fees high enough to cover costs (including normal returns). With explicit fees a firm would demand bank services only up to the point at which the value to the firm from an additional unit of service equals the cost to the bank of providing the service.

The history of bank competition for demand de. posits prior to the 1930s can perhaps provide some guidance on whether banks would pay explicit interest on demand deposits. Major money center banks frequently agreed to limit rates of interest on demand deposits, but often those agreements were undermined quickly by competitive behavior ${ }^{16}$ If banks failed at limiting rate competition on demand deposits prior to the 1930 s, when anti-trust prosecution of such collusive agreements was more lax, they probably would not be able to limit interest rate competition for demand deposits now, unless govermment sets the rate.

\section{Effects on Bank Profits}

The effects that explicit interest payments on demand deposits of business firms would have on earnings depends upon the implicit interest rates they have been paying. With limited information publicly available on individual bank-customer relationships, it is difficult to estimate the implicit interest rates banks are now paying. For banks now paying a competitive implicit interest rate, interest on deposits would have minimal effects on earnings. The staff of the Board of Governors made a rough estimate that explicit interest payments on demand deposits would increase the net costs of business demand deposits to banks by no more than one-half of one percent. ${ }^{17}$

\section{Effects on Bank Loan Interest Rates}

The analysis above has implications for another issue involved in the payment of interest on demand deposits: would banks raise their interest rates on

\footnotetext{
${ }_{16}$ Albert H. Cox, Jr, Regtilation of Interest on Bank Deposits (Ann Arbor, Michigan: Bureau of Business Research, University of Michigan, 1966), pp. 1-11.

17"The Impact of the Payment of Interest on Demand Deposits," pp. 44-45,
} 
loans to offset part of their increase in interest costs, if the prohibition of interest payments on demand deposits was lifted, and if they did so, what would be the reason? One condition under which banks might raise their loan rates in response to interest on demand deposits would be if banks have some monopoly power in the market for credit. If interest on demand deposits would raise the marginal costs of lending for banks, they would tend to raise their interest rates on loans, although not necessarily by enough to fully cover the increased cost of attracting funds.

A second possibility is that banks would invest more of their assets in higher risk, higher rate loans in order to cover the increased costs of interest payments on demand deposits. Concern that interest on demand deposits would induce banks to make high risk loans has been one of the reasons for prohibiting such interest payments since the early $1930 \mathrm{~s}^{18}$

However, there is a third condition under which banks would raise interest rates on some of their loans which would reflect neither monopoly power nor in* creased risk. If banks are currently paying implicit interest to business firms on their demand deposit balances in the form of lower loan rates than those offered other borrowers, banks would tend to raise the loan rates offered to their business depositors relative to the loan rates offered to other borrowers when they

\footnotetext{
Estudies by Benston and Cox found that evidence from the 1920 s and 1930s does not support the hypothesis that banks which paid higher interest rates on deposits had more risky assets or that banks which paid higher interest rates on deposits had greater tendency to fail. See George J. Benston, "Interest Payments on Demand Deposits and Bank Investment Behavior," Journal of Political Economy (October 1964), pp. 431-49, and Cox, Regulation of Interest on Bank Deposits.
}

began paying explicit interest on demand deposits. Such a reaction by banks would indicate that they had been competing indirectly for demand deposits under the prohibition on explicit interest payments, and not necessarly that banks have monopoly power in the market for credit or that banks would be making riskier loans.

\section{CONCUUSONS}

Studies of banking practices indicate that firms receive loans at preferential rates and bank services at low fees when they borrow or use services at banks where they keep demand deposit balances. Those studies also report that the demand deposit balances which firms hold as compensation for preferential loan rates or low-priced services are, in general, their working balances. These observations support the view that banks have been circumventing the prohibition of interest payments in competing for the demand deposit balances of business firms.

If banks were permitted to pay interest on the demand deposit balances of business firms directly, there would be some incentives for banks to do so. If banks did begin paying explicit interest, they would tend to offer depositors and nondepositors the same loan terms, and end the practice of requiring compensating balances of business borrowers. Banks that would substitute explicit for implicit interest payments would raise the interest rates they charge business depositors for loans and increase their fees on services. For banks currently paying competitive interest rates on the demand deposits of business firms through indirect means, payment of explicit interest would have small net effect on earnings.

\section{APPENDIX}

\section{Are Minimum Compensating Balance Requirements Rational?}

This appendix demonstrates that both a bank and borrower could benefit from eliminating minimum comw pensating balance requirements and, alternatively, that both banks and their customers can benefit from compensating balance requirements set in terms of average balances.

Suppose a bank has excess reserves of $\$ 840$ which it plans to lend to its customers. One customer wishes to borrow $\$ 800$. If the bank imposes a compensating balance requirement of 20 percent, it would lend the customer $\$ 1,000$ and require that $\$ 200$ be held in demand balances. If the bank's marginal reserve requirement on demand deposits was 20 percent, its required reserves would go up by $\$ 40$ due to creating the $\$ 200$ of net demand deposits, thus reducing the bank's excess reserves to zero. Thus, the bank would use the $\$ 840$ in excess reserves by making $\$ 800$ available to the customer to use 
as it wishes and by creating $\$ 200$ in compensating balances, which would increase its required reserves by $\$ 40$.

If the bank imposed minimum balance requirements, the customer would not be allowed to draw its demand balance below $\$ 200$. Those balances would not be useful to the customer for conducting transactions, and therefore, the customer would receive no benefit from holding them. Suppose the bank charges the customer 8 percent interest on the $\$ 1,000$. To the borrower this is an effective interest rate of 10 percent since he pays $\$ 80$ in interest annually, on the $\$ 1,000$ loan, but has use of only $\$ 800$.

Under these conditions, both the bank and the customer could benefit from eliminating the compensating balance requirement. If the bank lent $\$ 800$ to the customer without recuiring a demand balance, the bank would still have $\$ 0$ in excess reserves to invest, and the bank and the customer could share interest on the $\$ 40$. The customer would benefit from any reduction in its interest rate on the $\$ 800$ loan below 10 percent.

On the other hand, suppose the customer holds a $\$ 200$ average demand deposit balance and is willing to move that working balance account to the bank with $\$ 840$ in excess reserves if that bank will offer a favorable interest rate on a loam of $\$ 800$. Under such an arrangement the bank would lend $\$ 800$ to the customer, $\$ 40$ in reserves would be required on the $\$ 200$ addition to the bank's demand deposit liabilities, and the bank would, on average, have $\$ 200$ in additional excess reserves to invest.

Suppose the market rate of interest on loans to nondepositors is 10 percent. What rate of interest would the bank charge the customer with the $\$ 200$ average demand deposit balance on its loan of $\$ 800$ ? The answer depends upon the degree of competition among banks. As one case, suppose banks are perfectly competitive. Under that assumption, all benefits from compensating balance agreements are passed on to depositors. The bank in this example could increase its earning assets by $\$ 160$ under the compensating balance agreement; the customer deposits $\$ 200$, and as an offsetting effect, required reserves go up by $\$ 40$. At a market rate of 10 percent, the bank can eam an additional $\$ 16$ per year. Under perfect competition, the bank would charge the depositor $\$ 64$ per year on the $\$ 800$ loan, or 8 percent, which is $\$ 16$ below what the customer would be charged on the $\$ 800$ loan as a nondepositor. With an annual savings of $\$ 16$ in interest costs and a $\$ 200$ average demand deposit balance, the implicit interest rate on demand deposits is 8 percent.

In this example all benefits from the compensating balance agreement go to the depositor. However, if the bank offers the customer a smaller reduction in its loan interest rate below the market rate, both the bank and the customer can benefl from a compensating balance agreement compared to the situation with no compensating balance agreement. For instance, suppose the bank is willing to lend $\$ 800$ to the customer with the $\$ 200$ average demand deposit balance at $\$ 70$ interest per year, instead of $\$ 64$ as in the example above. The customer would have paid $\$ 80$ interest per year as a nondepositor, and therefore, is better off under this compensating balance agreement than it would be as a nondepositor. If the bank did not enter into this compensating balance agreement, it could earn $\$ 84$ from lending its $\$ 840$ of excess reserves to rondepositors. However, under this compensating balance agreement, the bank would earn $\$ 70$ from lending $\$ 800$ to the depositor and an additional $\$ 20$ per year from investing the depositor's average demand deposit balance.

This example illustrates how compensating balance agreements involve implicit interest payments on demand deposits under the following conditions:

(a) a depositor gets a lower loan rate than it would as a nondepositor,

(b) the bank allows the customer to satisfy the compensating balance requirement with its average balances, and

(c) the bank attracts additional reserves through the compensating balance agreement.

However, compensating balance agreements can involve implicit interest payments on demand deposits even if a bank loans a customer the compensating balance, as illustrated below.

Assume that all conditions are the same as in the example above except that the bank lends the customer $\$ 200$ which is to be held at the bank as a working balance. The customer also borrows $\$ 800$ for other purposes, thus borrowing $\$ 1,000$ in total. This transaction can be analyzed like that in the example above by treating the $\$ 1,000$ loan as being in two parts: first, the competitive bank lends the customer $\$ 200$ for a working demand deposit balance at the market interest rate of 10 percent, and then lends $\$ 800$ at 8 percent, taking into consideraw tion the $\$ 200$ average compensating balance. The average interest ate on the two loans would be 8.4 percent, with interest payments of $\$ 84$ per year. Since the customer would save \$16 per year by holding its average demand deposit balance of $\$ 200$ at the bank at which it borrows, its implicit interest return on demand deposits would be 8 percent.

Thus minimum compensating balance requirements are unprofiable for banks. since by creating demand deposit balances, which borrowers would hold as idle balances, banks increase their required reserves. Compensating balance requirements based upon the average balances of borrowers can be profitable for banks and their customers since the firms may use their demand deposits as compensating balances of as working balances, and banks retain the demand deposit liabilities they create from the excess reserve they lend to their customers. Throagh use of such compersating balance agreements banks and their customers are able to circumvent the prohibition of interest payments on demand deposits. 